\title{
Identification of off-Label Indications Drug for Pregnant Women in A Public Hospital in Yogyakarta Indonesia
}

\author{
P Utami ${ }^{1, *}$ N Maziyyah ${ }^{2}$ I Cahyaningsih ${ }^{3}$ B Rahajeng ${ }^{4}$ W Hariyadi ${ }^{5}$
}

\author{
1, 2, 3, 4, 5, School of Pharmacy, Faculty of Medicine and Health Sciences, Universitas Muhammadiyah Yogyakarta, Indonesia * \\ Corresponding author. Email : pinasti_wicaksana@gmail.com; pinasti.utami@umy.ac.id
}

\begin{abstract}
Pregnant women have special characteristics in the use of drugs that require more attention in the administration of drugs. The use of drugs outside the information listed in the leaflet or "off-label" has a risk when used by special populations such as pregnant women. This study aims to determine the identification of off-label indication drugs uses for pregnant women at hospitals. This study was conducted using a descriptive observational study with a cross-sectional approach. Sampling in this study used a retrospective method on medical records of pregnant women in a public hospital in Yogyakarta. The medical record samples amounted to 298 taken using systematic random sampling techniques from January to December 2016. The samples were then analyzed based on the information stated on the National Drug Information Center and related journals. The results showed that there were 2075 drug prescriptions in which there were 98 drug prescriptions (4.72\%) with an off-label indication category. Off-label indications drug use included 79 prescriptions of misoprostol (3.81\%), 16 dexamethasone prescriptions $(0.77 \%)$, and 3 prescriptions on ondansetron $(0.14 \%)$.
\end{abstract}

Keywords: Off-Label Indications Drug, Pregnant Women, Public Hospital in Yogyakarta

\section{INTRODUCTION}

A study conducted in the United States found 6276 prescriptions in which there were 2199 prescriptions (35\%) in the off-label category. The off-label prescription contains drugs that work on the central nervous system and hormones. Examples of off-label drugs used were haloperidol (33\%), chlorpromazine (13\%), dexamethasone (13\%), glycopyrrolate $(8 \%)$, hydromorphone (7\%), and morphine (7\%) [1]. Research on off-label in Indonesia is carried out by Rahajeng[2]. The study discusses the use of anticonvulsants as off-label. The results of the research is that have been done, the use of anticonvulsants as off-label includes oxcarbazepine $67.27 \%$, carbamazepine $46.15 \%$, pregabalin $45.45 \%$, phenytoin $37.62 \%$, valproic acid $25.34 \%$, and gabapentin $18.28 \%$.

Off-label drugs use is feared to have an unexpected effect if previous clinical trials have proven safety and effectiveness. Although there is enough evidence to justify off-label use, the Food and Drug Administration (FDA) is considered slow in updating information on off-label drugs use. Scientific evidence that proves the effectiveness of off-label use still requires FDA approval regarding the findings of the latest indications of the drug under study [3]. Examples of evidence of off-label drug indication use are biguanide (metformin) with indications of increasing cell sensitivity to insulin in diabetes but are used as a therapy for PCOS (Polycystic Ovary Syndrome) [4]. Misoprostol is supposed to be indicated as a treatment for gastric ulcer but is used as labor induction in preterm pregnancy [5].

According to Girardi, pregnant women with special conditions will experience physiological changes during their pregnancy[6]. These physiological changes will affect the pharmacokineties profile of the drug. Changes in the pharmacokinetic of drugs in pregnant women will affect the quality of their health. Drug selection in pregnant women must pay attention to safety and effectiveness is based on available scientific evidence (evidence-based). Therefore, research is about how widespread the use of off-label drugs is indicative especially in pregnant women.

\section{METHOD}

Design of study and sampling using a descriptive observational method with a cross-sectional approach and retrospective sampling. The subjects of this study were pregnant female patients in a public hospital in Yogyakarta during January-December 2016. Of 1203 population, it was obtained 292 as a minimum sample. Researchers determined 298 samples for sampling using systematic random sampling techniques. Research instruments were medical records, The National Drug Information Center Guidelines, and related journals. Data were analyzed using a percentage to calculate the use of off-label drug indications for pregnant women, as follow:

$$
P=\frac{f \times 100}{n}
$$

Note:

$\mathrm{P}=$ Percentage of off-label drug indications

$\mathrm{f}=$ Total number of prescriptions for off-label indications

$\mathrm{n}=$ Total number of drugs prescribing in the sample

$100 \%=$ Fixed number

\section{Ethical approval}

The study was approved by the The Ethics Committee of the Faculty of Medicine and Health Sciences, Universitas Muhammadiyah Yogyakarta No: 553/EP-FKIK$\mathrm{UMY} / \mathrm{X} / 2017$ 


\section{RESULT}

\subsection{Overview of Sample Prescribing}

The subjects of this study were pregnant female patients in Yogyakarta during Januari-Desember 2016 and there were 298 medical records samples from 1203 pregnant female populations. The following distribution of sample prescriptions can be seen in tables 1 and 2 (source: medic record data)

TABLe 1. OVERVIEW OF SAMPLE Distribution

\begin{tabular}{|c|l|c|c|c|}
\hline No. & Month & $\begin{array}{c}\text { Total } \\
\text { Population }\end{array}$ & $\begin{array}{c}\text { Number of Medical } \\
\text { records samples }\end{array}$ & $\begin{array}{c}\text { Total } \\
\text { Medication } \\
\text { Prescription }\end{array}$ \\
\hline 1 & January & 119 & 29 & 192 \\
\hline 2 & February & 99 & 25 & 187 \\
\hline 3 & March & 100 & 25 & 163 \\
\hline 4 & April & 109 & 27 & 184 \\
\hline 5 & May & 119 & 29 & 183 \\
\hline 6 & June & 113 & 28 & 193 \\
\hline 7 & July & 95 & 24 & 163 \\
\hline 8 & August & 100 & 25 & 185 \\
\hline 9 & September & 88 & 22 & 176 \\
\hline 10 & October & 102 & 25 & 179 \\
\hline 11 & November & 89 & 22 & 163 \\
\hline 12 & December & 70 & 17 & 107 \\
\hline & Total & $\mathbf{1 2 0 3}$ & $\mathbf{2 9 8}$ & $\mathbf{2 0 7 5}$ \\
\hline
\end{tabular}

TABLE 2. OVERVIEW OF DRUG PRESCRIPTION

\begin{tabular}{|c|c|c|}
\hline Drug prescription distribution & Total & Percentage \\
\hline Vitamin & 600 & $28.92 \%$ \\
\hline Promavit & 257 & $12.39 \%$ \\
\hline Vitamin A & 218 & $10.51 \%$ \\
\hline Cyanocobalamin & 37 & $1.78 \%$ \\
\hline Magnesium Sulphate & 31 & $1.49 \%$ \\
\hline Ferofort & 20 & $0.96 \%$ \\
\hline Folic acid & 8 & $0.39 \%$ \\
\hline Lactamor & 7 & $0.34 \%$ \\
\hline Alinamin F & 6 & $0.29 \%$ \\
\hline Ossoral & 6 & $0.29 \%$ \\
\hline Potassium Chloride & 4 & $0.19 \%$ \\
\hline Folamil & 1 & $0.05 \%$ \\
\hline Mecobalamin & 1 & $0.05 \%$ \\
\hline Venofer & 1 & $0.05 \%$ \\
\hline Potassium Gluconate & 1 & $0.05 \%$ \\
\hline Calcium carbonate & 1 & $0.05 \%$ \\
\hline Curcuma & 1 & $0.05 \%$ \\
\hline \begin{tabular}{|l|} 
Antibiotics \& Antifungals \\
\end{tabular} & 421 & $20.29 \%$ \\
\hline Cefadroxil & 160 & $7.71 \%$ \\
\hline Amoxicillin & 132 & $6.36 \%$ \\
\hline Cefixime & 112 & $5.40 \%$ \\
\hline Metronidazole & 13 & $0.63 \%$ \\
\hline Erythromycin & 1 & $0.05 \%$ \\
\hline Erlamycetin & 1 & $0.05 \%$ \\
\hline Meropenem & 1 & $0.05 \%$ \\
\hline Ketoconazole ointment & 1 & $0.05 \%$ \\
\hline Analgesics, Antipyretics, NSAIDs & 403 & $19.42 \%$ \\
\hline Mefenamic acid & 253 & $12.19 \%$ \\
\hline Ketorolac & 83 & $4.00 \%$ \\
\hline Paracetamol & 50 & $2.41 \%$ \\
\hline Dexketoprofen & 14 & $0.67 \%$ \\
\hline Ibuprofen & 2 & $0.10 \%$ \\
\hline Acetylsalicylic Acid & 1 & $0.05 \%$ \\
\hline Hormone & 252 & $12.14 \%$ \\
\hline Oxytocin & 127 & $6.12 \%$ \\
\hline Methylergometrin & 116 & $5.59 \%$ \\
\hline Progesterone & 9 & $0.43 \%$ \\
\hline Drug prescription distribution & Total & Percentage \\
\hline Cardiovascular & 199 & $9.59 \%$ \\
\hline Asam Traneksamat & 74 & $3.57 \%$ \\
\hline
\end{tabular}

\begin{tabular}{|c|c|c|}
\hline Lidocaine & 50 & $2.41 \%$ \\
\hline Nifedipine & 48 & $2.31 \%$ \\
\hline Methyldopa & 13 & $0.63 \%$ \\
\hline Furosemide & 12 & $0.58 \%$ \\
\hline Bisoprolol & 1 & $0.05 \%$ \\
\hline Diltiazem $\mathrm{HCl}$ & 1 & $0.05 \%$ \\
\hline Gastrointestinal & 123 & $5.93 \%$ \\
\hline Misoprostol & 79 & $3.81 \%$ \\
\hline Ranitidine & 18 & $0.87 \%$ \\
\hline Dexanta & 16 & $0.77 \%$ \\
\hline Dulcolax & 5 & $0.24 \%$ \\
\hline Omeprazole & 3 & $0.14 \%$ \\
\hline Sucralfate & 2 & $0.10 \%$ \\
\hline Corticosteroids & 25 & $1.20 \%$ \\
\hline Dexamethasone & 25 & $1.20 \%$ \\
\hline Liquid and Electrolytes & 23 & $1.11 \%$ \\
\hline Ringer Lactate & 15 & $0.72 \%$ \\
\hline Albumin & 6 & $0.29 \%$ \\
\hline $\mathrm{NaCl}$ & 2 & $0.10 \%$ \\
\hline Central Nerve System & 20 & $0.96 \%$ \\
\hline Tramadol & 7 & $0.34 \%$ \\
\hline Metoclopramide & 5 & $0.24 \%$ \\
\hline Ondansetron & 3 & $0.14 \%$ \\
\hline Bromocriptine & 3 & $0.14 \%$ \\
\hline Xylomidon & 1 & $0.05 \%$ \\
\hline Betahistine & 1 & $0.05 \%$ \\
\hline Respiratory & 5 & $0.24 \%$ \\
\hline Terbutaline & 2 & $0.10 \%$ \\
\hline Ambroxol & 2 & $0.10 \%$ \\
\hline $\mathrm{OBH}$ & 1 & $0.05 \%$ \\
\hline Antihistamines & 2 & $0.10 \%$ \\
\hline Cetirizine & 2 & $0.10 \%$ \\
\hline Urinary & 2 & $\mathbf{0 . 1 0 \%}$ \\
\hline Aminoral & 2 & $0.10 \%$ \\
\hline
\end{tabular}

The most prescribed medication given to pregnant women is the vitamin which is equal to 600 prescriptions (28.92\%). Giving vitamins to pregnant women has important benefits for restoring women's health during childbirth and increasing child survival [7].

\subsection{Use of Off-Label Drug Indication}

This study included 2075 drug prescriptions analyzed based on the National Drug Information Center and related journals. Based on the analysis carried out, there were 98 prescription drugs $(4.72 \%)$ with the category of off-label indications.

TABle 3. OVERVIEW OF OFF-LABEL USE

\begin{tabular}{|c|c|c|c|c|c|}
\hline No & Drug & $\begin{array}{c}\text { On-label } \\
\text { Indication }\end{array}$ & $\begin{array}{c}\text { Off-label } \\
\text { Indication }\end{array}$ & \begin{tabular}{|l|} 
Total \\
Presc \\
ribing
\end{tabular} & $\begin{array}{c}\text { Percen } \\
\text { tage }\end{array}$ \\
\hline 1 & Misoprostol & Peptic ulcer & $\begin{array}{l}\text { Labor } \\
\text { Induction }\end{array}$ & 79 & $\begin{array}{c}80.61 \\
\%\end{array}$ \\
\hline \multirow[t]{2}{*}{2} & $\begin{array}{l}\text { Dexamethaso } \\
\text { ne }\end{array}$ & \multirow{2}{*}{\begin{tabular}{|l} 
Inflammatory \\
suppression \\
(Corticosteroids)
\end{tabular}} & \multirow[t]{2}{*}{$\begin{array}{l}\text { Fetal Lung } \\
\text { Maturation }\end{array}$} & & \\
\hline & & & & 16 & $\begin{array}{c}16.33 \\
\%\end{array}$ \\
\hline \multirow[t]{3}{*}{3} & Ondansetron & \multirow{2}{*}{$\begin{array}{l}\text { Nausea Vomiting } \\
\text { due to } \\
\text { Chemotherapy }\end{array}$} & \multirow{2}{*}{$\begin{array}{l}\text { Nausea } \\
\text { Vomiting on } \\
\text { Pregnancy }\end{array}$} & & \\
\hline & & & & 3 & $3.06 \%$ \\
\hline & & Total & & 98 & $100 \%$ \\
\hline
\end{tabular}

\section{DISCUSSION}

Scientific evidence and strong medical reasons must support the use of off-label drugs. The therapy given to patients must have a good effect and ensure the therapy is 
effective and safe. The following is an explanation of the offlabel drug indications uses contained in this study:

\subsection{Misoprostol}

Based on the research that has been done there are 79 prescriptions (3.81\%) of misoprostol as an off-label indication drug category. The use of misoprostol in this study was categorized as an off-label indication as an induction of labor in preterm pregnancy [5].

Labor induction is the process of stimulating uterine contractions as an attempt to give birth through the vagina. Stimulation of uterine contractions can be performed either by medical or meditative measures before spontaneous onset of labor [8]. Labor induction has good potential for women who will give birth and their fetus. However, labor induction also has several risks, namely maternal intoxication, fetal heart rate abnormalities, cord prolapse, uterine hyperstimulation, uterine rupture, and increased risk of cesarean section labor [9]. There are two methods in the management of labor induction namely mechanically and pharmacologically. The mechanical method is to use a hygroscopic dilatator (laminaria) using a balloon catheter and amniotomy. Pharmacologically induced labor, which uses drugs such as oxytocin and prostaglandins [10].

In most countries in Africa, the drug approved for labor induction is oxytocin and ergometrine. The use of these two drugs is limited by a number of factors. First, it has a number of contraindications and potentially serious side effects. Second, it needs to be given intravenously (through a regulated infusion system) or intramuscularly, and ideally stored in the refrigerator. All these conditions are difficult to fulfill if the resources owned are limited. Some of these factors that cause the two drugs are not always effective because environmental factors influenced them. Although both drugs are effective in stimulating uterine contractions, they do not have a direct effect on the cervix. This is different from prostaglandin which is effective in both sites of action by inducing uterine contractions and ripening of the cervix [11].

According to the National Drug Information Center, misoprostol is indicated as a drug for the treatment of gastric, duodenal ulcers and ulcers caused by the use of nonsteroidal anti-inflammatory drugs (NSAIDs) [12]. Misoprostol is contraindicated in women planning to become pregnant or women who are pregnant because it can cause an increase in uterine tone[13].

In most countries, misoprostol has not been given a license or label for use in pregnancy. But because prices are cheaper, stable at room temperature, and effective in helping to increase uterine contractions, misoprostol is used in general and is used inappropriately according to the information on the drug label. Even though it is effective in causing uterine contractions, the use of high-dose misoprostol can cause uterine hyperstimulation and uterine rupture which can endanger pregnant women and their fetuses [14]. A German study on the use of misoprostol as an off-label for labor induction found that 355 respondents $(66 \%)$ reported using misoprostol for labor induction and 183 respondents (34\%) reported never using misoprostol for labor induction. The reasons for using misoprostol for labor induction are related to effectiveness $(40 \%)$, well received by patients $(35 \%)$, well proven in clinical practice $(35 \%)$, and cost-effectiveness (32\%). Reasons for not using misoprostol as labor induction because of its use as offlabel $(69 \%)$ and mismatch in granting legality (27\%) [5].

Misoprostol is a prostaglandin E1 synthesis analogue which was inaugurated by the FDA in 1985, as a drug to treat peptic ulcer due to the use of non-steroidal anti-inflammatory drugs because it is cytoprotective. Other characters possessed by prostaglandin E1 synthesis analogues are as uterotropin and uterotonin. The function of uterotropin in the labor phase is that prostaglandin causes the development of gap junction and ripening of the cervix, while the nature of uterotonin in the labor phase is prostaglandin can cause uterine contractions [10].

\subsection{Dexamethasone}

Based on the research that has been done there are 16 prescriptions $(0.77 \%)$ of dexamethasone as an off-label indication drug category. The use of dexamethasone in this study was categorized as an off-label indication as lung maturity in preterm pregnancy [15].

Labor process in preterm or premature pregnant women is at risk of having health problems such as respiratory problems in infants or called Respiratory Distress Syndrome (RDS). RDS is a respiratory disorder in babies born preterm and causes serious health problems such as neonatal defects and can cause death. Respiratory disorders that occur in infants can be caused due to surfactant deficiency, abnormalities of pulmonary anatomical development and immaturity in other organs. Surfactant is a complex mixture derived from lipids and apoprotein which serves to maintain stability when breathing and prevent damage to the alveoli. Premature babies are at risk of developing surfactant deficiencies that can cause RDS. Low lung volume during expiration results in high surface tension. This causes atelectasis, a mismatch of ventricular perfusion and eventually causes respiratory failure [16].

According to the National Drug Information Center, dexamethasone is a corticosteroid that has the effect of suppressing inflammation and allergic disorders[17]. However, there are studies that state that dexamethasone in women with a risk of preterm labor can overcome the incidence of RDS (Respiratory Distress Syndrome) [15].

Antenatal steroid treatment for women who give birth prematurely has evolved as an effective treatment for prevention of RDS, reducing early neonatal morbidity and mortality. Steroids that recommended for antenatal therapy are dexamethasone and betamethasone. There are no significant contraindications for steroid use as antenatal prophylaxis therapy. In the Cochrane meta-analysis of 18 RCTs, conducted by the University of Oxford in 2010 on behalf of the International Epidemiology Association and published at the Oxford Journals 2010, there is clear evidence that antenatal steroid therapy is effective in preventing neonatal death $(31 \%$ reduction) and morbidity (34\% decrease in RDS) [15].

Dexamethasone is a corticosteroid that has the potential as glucocorticoids and has no significant mineralocorticoid properties. Dexamethasone as glucocorticoid has physiological effects on the lung such as increasing lung volume ability, decreasing vascular surface tension, and improving the parenchymal structure and respiratory function. Dexamethasone is a long-acting glucocorticoid that can penetrate the placenta in an active form, dexamethasone 
phosphate solution. The mechanism of dexamethasone has the potential to overcome RDS with regard to the effects produced in increasing surfactant phospholipid synthesis in type II pneumocyte cells and increasing improvement in lung maturity. The synthesis of surfactant phospholipids requires lipogenic enzymes induced by corticosteroids. Another function of lipogenic enzymes produced is stimulating the production of antioxidants and protein surfactants [18].

\subsection{Ondansetron}

Based on the research that has been done there are 3 prescriptions $(0.14 \%)$ ondansetron as an off-label indication drug. The use of ondansetron in this study was categorized as an off-label indication as a therapy for nausea and vomiting in pregnancy [19].

NVP (Nausea and vomiting of pregnancy) is a condition that occurs during pregnancy. More than $90 \%$ of pregnant women experience NVP with varying severity [20]. The severity of NVP in pregnancy can be categorized into 3 , namely mild, moderate, to severe. Hyperemesis Gravidarum (HG) is the incidence of severe nausea and vomiting that requires treatment because it can cause serious complications and even death [21]. HG can cause fluid and electrolyte imbalances that are characterized by prolonged vomiting during pregnancy. Diagnosis of pregnancy nausea and vomiting is clinical, although the cause of nausea and vomiting in pregnancy is rarely found. Some of the factors that are known to cause NVP are excessive secretion of the hormone hCG (Human Chorionic Gonadotropin), physiological changes in organ systems in pregnant women such as gastrointestinal, increased placental period, Helicobacter Pylori bacterial infection, genetic predisposition, multiparas, and history of HG [20].

Management of therapy in pregnant women must pay attention to the risks of complications that will occur in pregnant women and their fetuses, and look for scientific evidence that supports the accuracy of therapy that given [22]. The search for scientific evidence on antiemetic drugs uses in pregnant women can provide an ideal picture of therapy. Information that includes the accuracy of dosage, efficacy, and safety of pregnant women and their fetuses needs to be considered [23]. Management of therapy for nausea and vomiting in pregnancy based on NVP Treatment Algorithm, drugs used that include doxylamine, pyridoxine, promethazine, metoclopramide, ondansetron, and hydrocortisone. It should be noted in some cases, ranitidine is needed as management of dyspepsia therapy in pregnancy [24]. According to National Agency of Drug and Food Control of Republik Indonesia, ondansetron is indicated as a treatment for vomiting caused by chemotherapy and radiotherapy, and prevention of nausea and vomiting after surgery[25]. However, there is research that states that ondansetron can be used as a treatment for nausea and vomiting in pregnancy [19].

Ondansetron is a drug that works selectively on 5Hydroxy-Tryptamine antagonist receptors or is called a 5-HT3 receptor and works on the vagal gastrointestinal afferent. The administration of serotonin antagonists is considered effective in reducing the incidence of nausea and vomiting during pregnancy [20]. The mechanism of action of ondansetron as a serotonin antagonist in the case of NVP is to block the action of serotonin receptors in the small intestine, vagus nerve, and chemoreceptor trigger zone. The mechanism of this action will reduce the stimulation of the chemoreceptor trigger zone and visceral afferent from the medulla vomiting center. Serotonin antagonists are the pharmacotherapy choice in treating the symptoms of nausea and vomiting caused by various causes because of their overall blocking of serotonin [26].

The research study was conducted by Murdiana regarding the treatment of nausea and vomiting in pregnancy in one of class D hospital [21]. The results of the study were $1.96 \%$ of vitamin B6 (first-line) and $27.4 \%$ of ondansetron administration as third-line therapy for nausea and vomiting in pregnancy. The administration of vitamin B6 or pyridoxine and ondansetron as a therapy for nausea and vomiting in pregnancy is assessed in accordance with the recommendations of ACOG (The American College of Obstetrics and Gynecologists). In this study, ondansetron was used as a second line in the guideline for hyperemesis gravidarum. The use of ondansetron as off-label in the case of NVP is widespread. A large number of uses of ondansetron as off-label in the treatment of NVP raises concerns, namely the negative impact related to patient's health condition, in addition to the price of ondansetron which is more expensive than other antiemetic drugs [19].

\section{CONCLUSION}

This study resulted in 2075 total prescribing drugs in which there were 98 drug prescriptions $(4.72 \%)$ with the category of off-label indications. Medications categorized as off-label indications include 79 prescriptions of misoprostol (3.81\%), 16 prescriptions of dexamethasone $(0.77 \%)$, and 3 prescriptions of ondansetron $(0.14 \%)$.

\section{REFERENCES}

[1] Kwon, Jung Hye, Min Ji Kim, Sebastian Bruera, Minjeong Park, Eduardo Bruera, and David Hui.2017. Off-Label Medication Use in the Inpatient Palliative Care Unit. Journal of Pain and Symptom Management, May. 2017 Jul;54(1):46-54. doi: 10.1016/j.jpainsymman.2017.03.014. Epub 2017 May 4.

[2] Rahajeng, Bangunawati, Zullies Ikawati, Tri Murti Andayani, and Iwan Dwiprahasto. 2018. A Retrospective Study: The Off-Label Use of Anticonvulsants at A Private Hospital in Indonesia. International Journal of Pharmacy and Pharmaceutical $\begin{array}{llll}\text { Sciences } & 10 & \text { (5): } & 119 .\end{array}$ https://doi.org/10.22159/ijpps.2018v10i5.25388.[3] Radley, David C., Stan N. Finkelstein, and Randall S. Stafford. 2006. Off-Label Prescribing among OfficeBased Physicians. Archives of Internal Medicine 166 (9): 1021-1026. https://doi.org/DOI: 10.1001/archinte.166.9.1021.

[4] Vitek, Wendy, Snigdha Alur, and Kathleen M. Hoeger. 2015. Off- Label Drug Use in the Treatment of Polycystic Ovary Syndrome. Fertility and Sterility 103 (3): 605-11. https://doi.org/10.1016/j.fertnstert.2015.01.019.

[5] Voigt, F., T.W. Goecke, L. Najjari, U. Pecks, N. Maass, and W. Rath. 2015. Off-Label Use of Misoprostol for Labor Induction in Germany: A National Survey. European Journal of Obstetrics \& Gynecology and Reproductive Biology $187 \quad$ (April): 8589. https://doi.org/10.1016/j.ejogrb.2014.11.026. 
[6] Girardi, Guillermina, Roberta Bulla, Jane E. Salmon, and Francesco Tedesco. 2006. The Complement System in the Pathophysiology of Pregnancy. Molecular Immunology $43 \quad$ (1-2): 68-77. doi:10.1016/j.molimm.2005.06.017

[7] Ministry of Health. 2009. VitA-Supplementation Guide.Pdf. http://gizi.depkes.go.id/wpcontent/uploads/2012/08/ VitA-Supplementation Guide .pdf.

[8] Permana, Gede Angga, Putera Kemara, and I Wayan Megadhana. 2014. Misoprostol for Induction of Labor in Pregnant Women. Thesis. Faculty of Medicine Udayana, Denpasar, 16.

[9] Wulandari, Isnamaya Kartika. 2012. Perbandingan Keberhasilan Persalinan antara Misoprostol dan Foley Kateter Pada Postterm, Thesis. Poltekkes Kemenkes Yogyakarta, 8.

[10] Puspa, Irene. 2016. Evaluasi Penggunaan Misoprostol Pada Kehamilan Postterm Di Bangsal Kebidanan RSUP Dr. M. Djamil Padang. Jurnal Iptek Terapan Volume $10 \mathrm{No}(3), 2016$. https://doi.org/10.22216/jit.2016.v10i3.578

[11] Weeks, Andrew D., Christian Fiala, and Peter Safar. 2005. Misoprostol and the Debate over Off-Label Drug Use. BJOG: An International Journal of Obstetrics and $\begin{array}{llll}\text { Gynaecology } & 112 & \text { (3): } 269-72 .\end{array}$ https://doi.org/10.1111/j.1471-0528.2004.00490.x.

[12] Pusat Informasi Obat Nasional (PIO Nas) | PIO Nas. 2018, [Electronic Version] Accessed 5 April 2018. http://pionas.pom.go.id/.

[13] Misoprostol | Pio Nas. 2018. [ Electronic Version ] Accessed 5 April 2018.

Http://Pionas.Pom.Go.Id/Monografi/Misoprostol.

[14] Alfirevic, Zarko, and Andrew Weeks. 2010. Oral Misoprostol for Induction of Labour. The Cochrane Library, Issue $2 . \quad 78$. https://doi.org/doi.org/10.1002/14651858.CD001338.p u b3.

[15] Shahzad, Fazeela, and Naima Umar. 2016. Impact of Antenatal Corticosteroids on Frequency and Mortality Due to Respiratory Distress Syndrome in Preterm Neonates. J Ayub Med Coll Abbottabad, August, 4.

[16] Roberts, Devender, Julie Brown, Nancy Medley, and Stuart R Dalziel. 2017. Antenatal Corticosteroids for Accelerating Fetal Lung Maturation for Women at Risk of Preterm Birth. Edited by Cochrane Pregnancy and
Childbirth Group. Cochrane Database of Systematic Reviews, March. https://doi.org/10.1002/14651858.CD004454.pub3.

[17] Deksametason | PIO Nas. 2018. [Electronic Version] $\begin{array}{llll}\text { Accessed } & 5 & \text { April } & \end{array}$ http://pionas.pom.go.id/monografi/deksametason.

[18] Ayu, Rembulan, and Ratna Dewi Puspita Sari. 2017. The Role of Corticosteroids in Maturation of Intrauterine Lungs. Thesis. Fakulty of Medicine, Universitas Lampung, June, 6.

[19] Colvin, Lyn, Andrew W. Gill, Linda Slack-Smith, Fiona J. Stanley, and Carol Bower. 2013. Off-Label Use of Ondansetron in Pregnancy in Western Australia. BioMed Research InternationalVolume 2013: page $1-8$.

https://doi.org/10.1155/2013/909860.

[20] Ebrahimi, Neda. 2010. Optimal Management of Nausea and Vomiting of Pregnancy. International Journal of Women's Heath ,2010 Aug 4;2:241-8., August, 24,

https://www.ncbi.nlm.nih.gov/pubmed/21151729https:// doi.org/10.2147/IJWH.S6794.

[21] Murdiana, Happy Elda. 2016. Therapy for Nausea Vomiting in Pregnancy at Outpatient Hospital Class D . Jurnal Ilmiah Farmasi12(2) Agustus-Desember 2016, 73-78

[22] Mattison, Donald R., ed. 2013. Clinical Pharmacology during Pregnancy. 1st ed. London; Waltham, MA: Academic Press.

[23] Feghali, Maisa N., and Donald R. Mattison. 2011. Clinical Therapeutics in Pregnancy. Journal of Biomedicine and Biotechnology Volume2011: 1-13. https://doi.org/10.1155/2011/783528.

[24] Institute of Obstetricians \& Gynaecologists. 2015. Guidelines- Ireland-Hyperemesis Nausea Vomiting in Pregnancy. November 2015. https://www.hyperemesis.ie/documents/GuidelinesIreland-Hyperemesis Nausea-Vomiting-inPregnancy.pdf.

[25] Ondansetron | PIO Nas. 2018. [Electronic Version] $\begin{array}{llll}\text { Accessed } & 5 & \text { April } & \end{array}$ http://pionas.pom.go.id/monografi/ondansetron.

[26] Widiasari, Ni Putu Ayu, I Gusti Made Surya, and Chandra Trapika. 2017. Pola Pemberian Terapi Mual dan Muntah pada Ibu Hamil oleh Dokter Spesialis Obstetri dan Ginekologi Serta Bidan Di Kota Denpasar. E-JURNAL MEDIKA Volume: 6 No:5 hal: 28035 